\title{
The Influence of Interpersonal Conflict on Counterproductive Work Behaviour Mediated by Job Stress
}

\author{
Nida Hasanati, TulusWinarsunu, \&Vironica Dwi Karina \\ University of Muhammadiyah Malang \\ nida3105@gmail.com
}

\begin{abstract}
High work productivity is the goal of organization, but reality shown today that the behaviour of counter-productive work done by many employees. Job stress and interpersonal conflict in the workplace create an atmosphere that is not conducive to assuming counter-productive behaviours. Purpose of this research is to know the influence of interpersonal conflict to the work behaviour of counter-productive which is mediated by job stress. Research design used non-experimental design with correlational research type. Sample in this research is a civil servant who amounted to 213 subjects taken from the total population who meet the criteria. Sampling technique used is cluster random sampling. Data collection instruments uses the Counterproductive Work Behaviour Checklist (CWBC) scale, Interpersonal Conflict at Work Scale (ICAWS), and Job Stress Inventory (JSI). This method uses Mediated Multiple Regression analysis technique. Hypothesis testing shows that interpersonal conflict in the workplace has a direct effect on counterproductive work behaviour, and workplace interpersonal conflict affects work-related counterproductive behaviour mediated by job stress.
\end{abstract}

Keywords: interpersonal conflict, counterproductive behaviour, job stress

\section{BACKGROUND}

Increasing work productivity is a dream in the organization, but the reality today, the counter-productive work behaviour occurs so much as the organizational performance decreases. Counterproductive behaviour is a serious problem for the organizations itself and the members inside (Fox, Spector \&Baurer, 2010). Such behaviour always in violates organizational norms and performs actions that are irrelevant to their goals, violates procedures, lowers probabilities (Klotz \& Buckley, 2013).

Counterproductive behaviour can be seen from the way people adapt to the surroundings such as how individuals accompany emotions, disappointments, and dissatisfaction in work (Bennet \& Robinson 2003). Dissatisfaction causes job stress on employees. Stress is a condition of tension that affects the emotions, thinking processes, and a person condition.

Behavioural counterproductive behaviour is reported to be spiralling out of control year by year, with almost $95 \%$ of all organizations reporting some counterproductive work behaviours in relation to high turnover and the emergence of counterproductive work behaviours such as absenteeism or work that is not done correctly (Mardanov, Heischmidt\& Henson, 2008).

In previous research, several terms have been used by researchers to describe negative work behaviours, such as deviant behaviour (Robinson \& Bennet, 1995), and counterproductive behaviour (Fox, Spector, \& Miles, 2001; Jones, 2009). In this case the term refers to the same meaning, which is the employee's negative work behaviour that can cost or harm the organization or members of other organizations. In this study, the researchers used the term work behaviour counterproductive. This is because in the context of work on the organization, the term is more commonly used and is an important component of employee performance appraisal (Sackett, 2002).

According to Vardi and Wiener (1996), counterproductive behaviour can occur across all sectors of the organization. Although counterproductive behaviour may occur it, some researchers argue that counterproductive behaviour is more common in public sector organizations than private sector organizations (Alias et al., 2012). Also supported by the results of Dick and Rayner's research (2013) indicating that there are indications of counterproductive behaviour (e.g., unemployed absenteeism, workplace intimidation, etc.) tend to be higher among employees working in public sector organizations compared to employees working in private sector organizations.

Bennet and Robinson (2000) also suggest that research on the behaviour of counterproductive work emphasizes the shape of behaviour itself rather than the outcomes or consequences of behaviour. From the results of the study disclosed that the deviation of employee work behaviour can be divided into two-dimensional direction, namely (1) behaviour of deviant work aimed at the organization; and (2) deviant work behaviour aimed at the interpersonal of other individuals (e.g., employers or co-workers).

Robinson and Bennet (1995) categorize deeds in the workplace into four categories: minor and organizational categories, serious and organizational, minor interpersonal, and serious interpersonal. The division in these quadrants becomes the basis of counterproductive work behaviour studies.

Gruys and Sackett (2003) describe the factors that characterize counterproductive behaviour that is the misuse of time and resources, i.e. wasting time and doing 
personal business during working hours, withdrawals consisting of behaviours that limit the amount of working time of the organization late or work early. (Spector et al., 2006) reveals five dimensions of counter-productive work behaviour that are actions that disturb or harass others, production deviations, theft, withdrawal (reduction of working time), and sabotage.

Counterproductive behaviour is a behaviour intended to disrupt the organization and its members (Penney \& Spector, 2002). Negative behaviour can be said to be distorted, such as absenteeism, withdrawal, business reductions, and behaviour causing organizational losses (Robinson \& Bennet, 1995). This happens on an interpersonal or organizational level. At this interpersonal level include behaviours (such as verbal abuse, favouritism and gossip etc.) that affect employees in the organization.

Interpersonal conflict refers to how well individuals can interact with others in the workplace, for example, how often others are abusive, evil, or yell at the individual (Spector Jex, 1998), and is one of the psychosocial stressors that has been linked to workplace counterproductive behaviour (Miles, Borman, Spector, \& Fox, 2002).

Interpersonal conflict in the workplace has been associated with various behavioural, psychological, behavioural and physical health outcomes. At the level of behaviour, interpersonal conflict has been associated with an increase in counterproductive behaviour (Bayram, Gursakal, \&Bilgel, 2009; Penney \& Spector, 2005), reduced attendance and work performance (Aquino \&Bommer, 2003).

In this case the interpersonal conflict in the workplace has been shown to have a positive relationship with counterproductive work behaviour and in some cases, has been found to be one of the strongest predictors of counterproductive work behaviour from various other work stressors (Bayram, Gursakal, \&Bilgel, 2009). Other studies have found that interpersonal conflict is associated with poor work attitude and psychological states such as job dissatisfaction, organizational commitment, negative emotions, and emotional fatigue (Frone, 2000; Giebels\& Janssen, 2005; Liu, Spector \& Shi, 2007; Spector \&Jex, 1998) Riggio (2009) defines that interpersonal conflict is a conflict that occurs when two individuals try to achieve their goals to hinder the achievement of others. The causes of interpersonal conflict are competition over resources, task description blurring as well as communication barriers and individual traits. Reinforced by Chen and Spector (1992) research indicates that interpersonal conflict has a significant positive correlation with sabotage, interpersonal aggression, hostility and complaints, and intention to quit. Conflicts have been found to be positively and significantly associated with counterproductive behaviours.

Bergmann and Volkema (1994) examine behavioural responses to interpersonal conflict. Responses such as avoiding people; form an alliance; not talking to people; or not cooperating with a more general person when the source of the conflict is a co-worker rather than a supervisor. Conversely speaking behind the person or sabotaging is more common when the source of the conflict is the supervisor of the co-worker.

Researchers have previously found that counterproductive behaviour is a consequence of many factors. Such as: personality traits of narcissism and anger and dissatisfaction (Fatima et al, 2012; Muafi, 2011), jealousy and negative emotions (Krischer, Penney \& Hunter, 2010; Khan, Peretti\&Quratulain, 2010). In addition, unclear job descriptions, insecurity in employment, lack of internal career opportunities and inappropriate judgment systems (Shamsudin, Subramaniam \& Ibrahim, 2011), lack of motivation (Osezua et al, 2009), poor supervision and conditions Stress (Fox et al., 2001) intention to stop and Company's contempt (Muafi, 2011), injustice (Fatima et al., 2012), cannot accept the group (Wing lo et al., 2011) are some other stimulus counterproductive work behaviours.

The counterproductive work behaviour that occurs can be caused by several factors. In general, the antecedents of this behaviour can be classified into two factors: (1) individual differences, personality traits, demographic characteristics, seniority, emotional intelligence, etc. and (2) situational factors, such as organizational justice, leadership style, organizational goals perceived and so forth (Douglas, Martinko\& Gundlach 2002). This study focuses on stress factors because stress is also a significant factor of counterproductive work behaviour (Onyishi and Onukwo, 2014).

Excessive job stress can have a negative impact on employee performance that ultimately cost the company. Negative impacts are low productivity, lack of motivation, ineffective decision making, low quality in between employee communication, high absenteeism, and even the emergence of violent acts in the work environment (Quick et al., 2002).

The counterproductive work behaviour is predicted by many negative work experiences such as interpersonal conflict, frustration, and work stress, and is conceptualized as a negative reaction (Bruursema, Kessler \& Spector, 2006; Jones, 2009; Marcus \& Wagner, 2007). Other findings illustrate that counterproductive behaviour as a stress-based emotional response to organizational conditions (Fox, Spector, \& Miles, 2001).

According to Spector and Fox (2005), deviant behaviour in the workplace occurs because employees react to job stress and other factors that can cause negative emotions. Other studies have also shown that job stress is a major factor causing some form of deviant behaviour (Spector \& Fox, 2005) and among other forms of irregularities that are absenteeism, alcoholism, substance abuse, low work motivation and low productivity (Safaria et al., 2010)

The Maiyer\& Spector (2013) study on job stress and counterproductive work behaviours using 663 subjects 
with longitudinal studies for 8 months showed a reciprocal effect of work stress affecting counterproductive work behaviour.

Based on the above explanation, the researcher assumes that job stress can be a mediating variable on the influence of interpersonal conflict on counterproductive work behaviour. It is said that interpersonal conflict has a positive relationship with work stress and counterproductive work behaviour and because work stress is antecedent of counterproductive work behaviour. Therefore, the researcher considers that it is important to conduct research on the influence of interpersonal conflict on counterproductive behaviour mediated by job stress. This study aims to determine the effect of interpersonal conflict on counterproductive work behaviour and the influence of interpersonal conflict to counterproductive work behaviour mediated by job stress.

\section{Figure 1. Framework of Thinking}
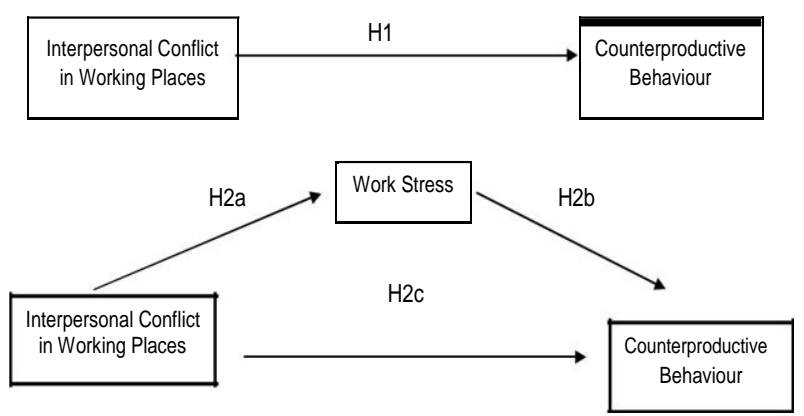

\section{Hypothesis}

H1: There is a direct influence of interpersonal conflict in the workplace on counterproductive job behaviours.

$\mathrm{H} 2$ : There is an effect of interpersonal conflict in the workplace to counterproductive behaviour mediated by job stress.

\section{RESEARCH METHODS}

\section{Research Design}

This study uses a quantitative approach with numerical data (numbers) that are analysed by statistics (Cresswell, 2012). While the design in this study using correlational design is a study that discusses the relationship between two variables or more (Sugiyono, 2010). This study was conducted to determine the extent of the influence of interpersonal conflict in the workplace against the counterproductive behaviour mediated by job stress.

\section{Research Subjects}

Subjects in this study are Civil Servants in Probolinggo City. The sampling technique used is Cluster Sampling where this method is used because the scope of the research is very wide. This sampling technique is used if the population not only consists of individuals but groups of individuals or clusters (Sugiyono, 2015). This technique is used because the subject studied consists of several groups based on the workplace, namely the Department of Education and culture and the Office of KPU in the city of Probolinggo east Java. Participants in this study were 213 people, in the education and cultural offices as many as 163 people $(76.52 \%)$ and the KPU office as many as 50 people (23.47) in the city of Probolinggo East Java. Description of characteristics of study subjects by sex, age, years of service, and last education can be seen in table 1 .

Table 1. Description of Subject Characteristics $(\mathbf{N}=$ 213)

\section{Total (N) Percentage (\%)}

Sex

$\begin{array}{lll}\text { Male } & 98 & 46 \\ \text { Female } & 115 & 53\end{array}$

Age

20-40 years old $6 \quad 40,4$

41-60 years old $127 \quad 59,6$

Working Period

$<10$ years 9

$0-19$ years $\quad 40 \quad 18,8$

$0-29$ years $\quad 35 \quad 16,4$

$\begin{array}{lll}\geq 30 \text { years } \quad 59 & 27,7\end{array}$

Education

High

School $20 \quad 9,8$

Diploma $63 \quad 29,6$

Bachelor108 $\quad 50,7$

Master $2 \quad 0,9$

\section{Variables and Research Instruments}

Data collection using Counterproductive Work Behaviour (CWB-C) questionnaire Spector, et al. (2006). The number of items as many as 43 items that measure the work behaviour of individuals in the workplace that disrupt the organization and its members. One example of the item on the scale is "I feel excessive in using material / work equipment" with the likert format $(1=$ never up to $5=$ Almost always $)$. Cronbach's reliability coefficient $(\square)=0.95$. 
Interpersonal conflict in the workplace is measured using the Interpersonal Conflict At Work Scale (ICAWS) scale compiled by Spector (1998) and developed by the researcher. This scale consists of 12 items to measure about the interpersonal contradictions arising when perceiving negatively to another individual, one example of an item on this scale is "How often do you get involved in argument with someone at work?" With Likert format ( $1=$ no ever up to $5=$ Almost always). The focus of the study is a perceived poor state of the individual with other individuals in the workplace. Reliability of cronbach's alpha $(\square)=0.93$.

While Job Stress was measured using Job Stress Inventory (JSI) compiled by John Canon \& Arbor Family Counselling (2012) which consists of 42 items. This scale consists of several aspects that can affect work stress such as 1). Lack of control, 2). Information gap, 3). Cause and effect, 4). Conflict 5). Alienation 6). Overload, 7). Underload, 8). Environment, 9). Value conflict. One example of the items on this scale is "I cannot be myself at work because I feel different from my colleagues". with Likert format $(1=$ never up to $5=$ Almost always). The reliability coefficient of cronbach's alpha $(\square)=0.94$.

\section{Data Analysis}

The data analysis used in this research is using Mediated Multiple Regression technique by using SPSS for Windows version 21 program. This analysis technique is used to measure the influence of interpersonal conflict $(\mathrm{X})$ variables in the workplace to the mediated (Y) (mediated behaviour of counterproductive behaviour) by job stress (M). This technique aims to examine the effect of mediation variables in mediating the relationship of variables (X) to (Y) (Hayes \& Preacher, 2013).

\section{Research Result}

Based on the analysis obtained the mean value, standard deviation, and inter-correlation on all research variables. Description of data can be seen in table 2 .

Table 2. Mean, Standard deviation and Relation between variables $(N=213)$

\begin{tabular}{|c|c|c|c|c|}
\hline Variables & Mean SD & 1 & 2 & 3 \\
\hline Counterproductive Behaviour & $3,180,52$ & - & $0.56^{* *}$ & $0.54 * *$ \\
\hline $\begin{array}{l}\text { Job Stress } \\
\text { Conflict }\end{array}$ & $3,200,50$ & & - & $0.58 * *$ \\
\hline Interpersonal in Work Places & $3,500,76$ & & & - \\
\hline
\end{tabular}

The results of descriptive analysis show that the average value of counterproductive behaviour 3.18, the average value of job stress 3.20 and the average value of interpersonal conflict in the workplace 3.5. In general, it can be concluded that to counterproductive behaviour, work stress and interpersonal conflict are in the middle level.

Table 3. Regression Results of Beta Coefficients

\begin{tabular}{lcccc}
\hline \multicolumn{1}{c}{ Influence } & $\boldsymbol{\beta}$ & $\mathbf{T}$ & Sig. & $\mathbf{R}^{2}$ \\
\hline $\begin{array}{l}\text { Direct } \\
\text { interpersonal }\end{array}$ & 0.53 & 9.304 & 0.00 & 29 \\
$\begin{array}{l}\text { conflict to } \\
\text { counterproductive }\end{array}$ & 9 & & 0 & $\%$ \\
behaviour. & & & & \\
\hline $\begin{array}{l}\text { Interpersonal } \\
\text { conflict in the }\end{array}$ & 0.56 & 9.863 & 0.00 & 31 \\
$\begin{array}{l}\text { workplace to job } \\
\text { stress }\end{array}$ & 2 & & 0 & $\%$ \\
& & & & \\
\end{tabular}

\begin{tabular}{lcccc}
\hline Job stress on & 0.58 & 3.695 & 0.00 & 52 \\
counterproductive & 1 & & 0 & $\%$ \\
work behaviour by & & & & \\
controlling & & & & \\
interpersonal & & & & \\
conflict in the & & & & \\
workplace. & & & &
\end{tabular}

$\begin{array}{lcccc}\text { The influence of } & 0.21 & 10.06 & 0.00 & 52 \\ \text { interpersonal } & 3 & 9 & 0 & \% \\ \text { conflict in the } & & & & \\ \text { workplace against } & & & & \\ \text { counterproductive } \\ \text { work behaviour by } \\ \text { controlling work } \\ \text { stress. }\end{array}$

In the data analysis (Table 3) it can be seen that interpersonal conflict in the workplace has a direct and significant effect on counterproductive behaviour $(\beta=$ $0,539 ; \mathrm{p}<0,00)$ (h1 accepted). This means that the higher the interpersonal conflict in the workplace the higher the counter-productive work behaviour, as well as vice versa that the lower the interpersonal conflict in the workplace the more lace also the counter-productive behaviour of work. Judging from the value of R2 $=0.291$ which means interpersonal conflict in the workplace can explain variant of work behaviour of counterproductive equal to $29 \%$

In the data analysis results (Table 3 ) it can be seen that interpersonal conflict in the workplace positively affects job stress $(\beta=0,562 ; \mathrm{p}<0.00)$. This shows the higher the interpersonal conflict in the workplace the higher the job stress. Judging from the value of R2 = 0.316 which means interpersonal conflict in the workplace can explain the variant of job stress behaviour by $31 \%$. The other findings suggest that there is a positive and significant influence on job stress variables on counterproductive work behaviour when under controlled conditions by interpersonal conflict at work ( $\beta$ $=0,581 ; \mathrm{p}<0,00)$ This means that the work stress variable becomes the intermediate variable on the 
influence workplace interpersonal conflict against counterproductive work behaviours. The value of R2 = 0.522 means work stress can explain the variant of counterproductive behaviour of $52 \%$. While the influence of workplace interpersonal conflict to work behaviour of counterproductive by controlling work stress got result $(\beta=0,0213 ; p<0,00)$ hence that mean interpersonal conflict variable at work influence counterproductive work behaviour with condition of work stress. The value of $\mathrm{R} 2=0.522$ means that workplace interpersonal conflict can explain the variant of counterproductive behaviour of $52 \%$.

Found indirect effect of $\beta\left(c^{\prime}\right)=0,213, p=0,00$. In determining the mediation variables there is a comparison of the results of the coefficients between the direct and indirect variables $\left(\mathrm{a}=0.562 \times \mathrm{b}=0.581>\mathrm{c}{ }^{\prime}=\right.$ 0.213 ). The results show that $0.326>0.213$ and $c=0.539$ - $c{ }^{\prime}=0.213$, then in this case indicates that the interpersonal conflict in the workplace against counterproductive work behaviour can be through work stress. In other words, work stress experienced by individuals is an intermediary between the influence of interpersonal conflict in the workplace and counterproductive work behaviour. So that can be interpreted that mediation that happened is partial mediation. MacKinnon and David (2008) Partial mediation shows that job stress can bridge the indirect influence of counterproductive work behaviour to interpersonal conflict in the workplace but even without job stress as a mediating variable, positive counterproductive work behaviour still has a significant direct effect on conflict interpersonal at work.

\section{DISCUSSION}

The results of this study indicate that there is a significant positive influence between workplace interpersonal conflict on counterproductive work behaviour, workplace interpersonal conflict to work stress, work stress on counterproductive work behaviour, and the influence of workplace interpersonal conflict on stress-mediated counterproductive behaviour work. this suggests that interpersonal conflict in the workplace has an impact on job stress and counterproductive work behaviour on employees.

Interpersonal conflict in the workplace has a significant direct positive effect on the counterproductive behaviour of employees. Where the higher the interpersonal conflict in the workplace the higher the behaviour of counterproductive work on the employees as well as vice versa, the lower the interpersonal conflict that occurs in the workplace the lower the counterproductive behaviour. This is in line with Spector, Dwyer \&Jex (1998) research that interpersonal conflict causes negative emotional reactions such as anger or shifting desire. And the causes of interpersonal conflict to counterproductive behaviour in mediation by negative emotions. (Fox, Spector, \& Miles, 2001).

Interpersonal conflict relations in the workplace has a significant positive effect on job stress. The higher the conflicting employees with colleagues in the workplace the higher the level of employee work stress, and vice versa if the lower the employee in conflict with his colleagues at work then the lower the level of employee job stress. This suggests that workplace conflicts resulting from interpersonal relationships can increase a person's work stress or an employee experiencing negative stress (distress) associated with the interpersonal (McShane and Glinow, 2008).

According to McShane and Glinow (2008) explains that the source of interpersonal conflict includes personal differences, communication problems, task dependencies, scarce resources, ambiguity rules, and objective mismatch. Meanwhile, according to Luthans (2011) interpersonal conflict stems from personal differences, information deficiency / communication problems, role mismatch, and environmental stress. Thus, an individual who does not want to accept ideas or ideas from other individuals when carrying out duties or relationships with other individuals will lead to conflict that can cause a employees to experience work stress.

In the results of this study also showed no effect of work stress with counterproductive work behaviour. This suggests that a high work stress in a person will increase the counterproductive work behaviour. If a person has a job stress, then he will perform a negative behaviour or action in his workplace. As for the results of this study found that there is the influence of workplace interpersonal conflict on the behaviour of counterproductive work mediated by work stress. It can be said that when the interpersonal conflict in the workplace that perceived employee is higher so it can directly increase job stress and then affect the increase of counterproductive work behaviour on the employee, and vice versa when the interpersonal conflict in the workplace is low then also the stress of work perceived by employees so that the effect on the low behaviour of counterproductive work.

Job stress is a variable that can mediate factors affecting counterproductive work behaviour. This is relevant with Onyishi and Onukwo (2013) research which states that job stress is a significant factor of counterproductive work behaviour. Thus, interpersonal conflict in the workplace requires job stress as a mediation so that it can give effect to the increase of counterproductive work behaviour. This is reinforced by the findings of the research of Oplenz and Spector (2013) and Spector, et al (2006) which explains that stress in the world of work can improve counterproductive work behaviour. 


\section{CONCLUSIONS AND RECOMMENDATION}

This study proves that there is a direct influence of interpersonal conflict on counterproductive work behaviour on civil servants and there is an indirect effect of interpersonal conflict on counterproductive work behaviour mediated by job stress on civil servants. Researchers then expected to be more able to dig deeper factors and other variables such as organizational justice, personality, and leadership styles that also influence the behaviour of counterproductive work not studied in this research.

\section{REFERENCE}

Aquino, K., \&Bommer, W. H, 2003. Preferential mistreatment: How victim status moderates the relationship between organizational citizenship behaviour and workplace victimization. Organizational Science, 14(4), 374-385.

Bayram,Gursakal, \&Bilgel. (20019). Counterproductive Work Behaviour Among White-Collar Employees: A study from Turkey. International Journal of Selection and Assessment. Volume 17, Issue 2, 180-188

Bergmann, T. J., \&Volkema, R. J. (1994). Issues, behavioural responses and consequences in interpersonal conflicts. Journal of Organizational Behaviour, 15, 467-471.

Bruursema, K. (2004). Leadership style and the link with counterproductive work behaviour (CWB):An investigation using the job-stress/CWB model. Unpublished master's thesis, University ofSouth Florida, Tampa, FL

Bennett, R. J., \& Robinson, S. L. (2000). Development of a measure of workplace deviance. Journalof Applied Psychology, 85, 349-360.

Chen, P. Y., \& Spector, P. E. (1992). Relationships of work stressors with aggression, withdrawal, theft and substance use: An exploratory study. Journal of Occupational and OrganizationalPsychology, 65, 177184.

Cresswell (2012). Educational Research: Planning, Conducting, and Evaluating Quantitative and Qualitative Research. Pearson Education, Inc.: Boston.

Dick, G.P.M. \& Rayner C.(2013). Negative Interpersonal Behaviour at Work: An Evidence Based Classification of Workplace Bullying. International Journal of Psychology and BehaviouralSciences, 3(4): 95-108

Douglas, S. C., \&Martinko, M. J. (2001). Exploring the role of individual differences in the prediction of workplace aggression. Journal of Applied Psychology, 86, 547559.

Fatima, A., Atif, K., Saqib, A., Haider, A. (2012). A Path Model Examining the Relations among Organizational
Injustice, Counterproductive Work Behaviour and Job Satisfaction. InternationalJournal of Innovation, Management and Technology, 3(6), 697-701.

Fox, S. and Spector, P. E. (2005). Counterproductive Work Behaviour: Investigations of Actors and Targets. Washington, DC: American Psychological Association.

Fox, S., Spector, P. E., and Miles, D. (2001). Counterproductive Work Behaviour in Response to Job Stressors and Organizational Justice: Some Mediator and Moderator Test for Autonomy and Emotions. Journal of Vocational Behaviour, 59 (3) : 291-309

Fox, S., Spector, P. E., \&Bauer, J . A. (2010). Measurement Artefacts in the Assessment of Counterproductive Work Behaviour and Organizational Citizenship Behaviour: Do We Know What We Think We Know? Journal of Applied Psychology, 781-790.

Frone, 2000. Interpersonal conflict at work and psychological outcomes: testing a model among young workers. $J$ Occup Health Psychol. 5(2):246-55.

Giebels, E. \& Janssen, O. 2005. Conflict stress and reduced well-being at work: The buffering effect of third-party help. European Journal of Work and Organizational Psychology. 14, 2, p. 137-155 19

Gruys, M. L., \& Sackett, P. R., (2003). Investigating the dimensionality of counterproductive work behaviour. International Journal of Selection and Assessment, 11(1), 30-42.

Jones,D. A. (2009). Getting even with one's supervisor and one's organization: Relationships among types of injustice, desires for revenge, and counterproductive work behaviours. Journalof Organizational Behavior, $30(4), 525-542$.

Khan, A., Quratulain, S., Peretti, J., 2010. Organizational Justice, Discrete Emotions and

Counterproductive Work Behaviors, 25th annual meeting of "Society for industria and organizational psychology", April 8-10, 2010. Society for industrial and organizational psychology, Atlanta, USA.

Klotz, A. C ., \& Buckley, M. R. (2013). A historical perspective of counterproductive workbehaviour targeting the organization. Journal of Management History 114-132

Krischer MM $^{1}$, Penney LM, Hunter EM. 2010 .Can counterproductive work behaviours be productive? CWB as emotion-focused coping. J Occup Health Psychol. Apr;15(2):154-66.

Laurenz,Meirer L \& Paul E. Spector. 2013. Reciprocal Effects of Works Stressors and Counterproductive Work Behaviour: A Five-Wave Longitudinal Study. Journal OfAppliedPsychology. 98(3):529.

Liu, C. (2003). A comparison of job stressors and job strains among employees holding comparablejobs in western and eastern societies. Unpublished doctoral dissertation, University of SouthFlorida, Tampa, FL. 
Luthans (2011) OrganizationalBehaviour:An Evidence-Based Approach. Published by McGraw-

Hill/Irwin : New York

Mardanov,I. T., Heischmidt, K., \& Henson, A. (2008). LeaderMember Exchange and Job Satisfaction Bond and Predicted Employee Turnover. Journal of Leadership \& Organizational Studies, 158-175.

McShane, SL. and MAV, Glinow. 2008. Organizational Behaviour Fourth Edition. Mc Graw Hill Irwin, Companies, inc. New York.

Meier, L. L., \& Spector, P. E. (2013). Reciprocal effects of work stressors and counterproductive work behaviour: A five-wave longitudinal study. Journal of Applied Psychology, Advance online publication.

Miles, D.E., Borman, W.E., Spector, P.E. and Fox, S. (2002). Building an Integrative Model of Extra Role Work Behaviours : A Comparison of Counterproductive Work Behaviour with Organizational Citizenship Behaviour. International Journal of Selection and Assessment (1/2 March /June) : 51-57

Muafi. 2011. Causes and Consequence Deviant Workplace Behaviour International. Journal of Innovation, Management and Technology, Vol. 2, No. 2.

Onyishi, I.E. \&Onunkwo, C.B.2014.Counterproductive Work Behavior among School Teachers The Contribution of Psychological Contract Breach and Job Stress. The African Symposium: An Online Journal of the African Educational Research Network. Volume 14

Osezua, M., E., Daniel, O., A., Emmanuel, E, G. (2009). Staff Indiscipline and Productivity in the Public Sector in Nigeria. An International Multi-Disciplinary Journal, Ethiopia, 3, 461-471.

Penny,L., \& Spector, P. (2005). Job stress, incivility, and counterproductive work behavior (CWB): The moderating role of negative affectivity. Journal of Organizational Behavior, 26(7), 777-796.

Quick, James C., Jonathan D., dkk (2002), Preventive Stress management in Organization, Washington DC, APA Order Department.

Robinson,S. L., \& Bennett, R. J. (1995). A typology of deviant workplace behaviours: A multidimensional scaling study. Academy of Management Journal, 38, 555-572.

Sackett, P. R. (2002). The Structure of Counterproductive Work Behaviours: Dimensionality and Relationships with Facets of Job Performance. International Journal of Selection \&Assessment, 10(1-2), 01-11

Shamsudin,F., Subramaniam, C., Ibrahim, H., (2011). HR Practices and Deviant Behaviour at Work: An Exploratory Study, 2011 International Conference on Business and Economics Research.

Spector, P. E. (2002). Employee control and occupational stress. Current Directions in Psychological Science, 11, 133-136.
Spector, Paul E, Suzy Fox, Lisa M. Penney, Kari Bruursema, Angelina Goh \& Stacey Kessler. 2006. The Dimensionality Of Counter productivity: Are All Counterproductive Behaviour Created Equal? Journal of Vocational Behaviour, 68: 446-460.

Spector, P. E., Fox, S., Penney, L. M., Bruursema, K., Goh, A., \& Kessler, S. (2006). The dimensionality of counter productivity: Are all counterproductive behaviours created equal? Journal of Vocational Behaviour, 68(3), 446-460.

Spector, P. E. (1998). A control theory of the job stress process. In C. L. Cooper (Ed.), Theories of organizational stress (pp. 153-169). Oxford, UK: Oxford Univ. Press.

Sugiyono. (2015). Metode Penelitian

Pendidikan(Pendekatan Kuantitatif, Kualitatifdan $R \& D)$. Penerbit CV. Alfabeta: Bandung.

Wing Lo, T., Cheng, C., Wong, D., Rochelle, T., Kwok, S., (2011). Self-Esteem, Self Efficacyand Deviant Behaviour of Young People in Hong Kong, Advances in Applied Sociology, 1(1), 48-55.

YoavVardi, Y \&Yoash Wiener, Y. 1996. Misbehaviour in Organizations. A $\quad$ Motivational Framework.Organization Science/Vol.7, No. 2. 